\title{
Limites e Lugares: entre caminhos Mẽbêngôkre
}

\author{
Ester Oliveira $^{1}$ \\ João Lucas Moraes Passos ${ }^{1}$ \\ ${ }^{1}$ Universidade de Brasília (UnB), Brasília, DF, Brasil
}




\section{Resumo}

Este trabalho reúne duas pesquisas feitas entre os Mẽbêngôkre, povo jê, mais conhecido como Kayapó e habitante da bacia do Xingu. Realizadas em dois subgrupos distintos, no Pará (TI Kayapó) e no Mato Grosso (TI Capoto/Jarina). As etnografias aqui trabalhadas voltam sua atenção para a territorialidade mẽbêngôkre, explorando as andanças e a produção de redes de lugares-eventos nomeados, intimamente ligadas à organização sociopolítica desse povo. Os deslocamentos ainda são pouco explorados na literatura antropológica sobre os Mẽbêngôkre, apesar de constituírem tema praticamente onipresente nas narrativas dos anciãos. Partimos das enunciações toponímicas nesses relatos para observarmos a dinâmica da produção de lugares e sua relação com as separações históricas dos subgrupos mẽbêngôkre; onde também estão em jogo práticas estatais, como a demarcação das terras e o estabelecimento de limites estaduais, que, embora contrastando com a territorialidade mẽbêngôkre, acabam por fornecer um idioma para as relações políticas entre os diferentes subgrupos.

Palavras-chave: Territorialidade. Lugares. Movimento.

\section{Abstract}

We gather here two studies among the Mẽbêngôkre, a gê people best known as Kayapó, who inhabits the Xingu river basin. Carried out in two distinct subgroups, in the states of Para and Mato Grosso, the ethnographies in question here draw attention to the mẽbêngôkre territoriality, exploring the journeys and the production of named places-events, intimately connected to the sociopolitical organization. The movements are not very well explored in the anthropological literature about the Mẽbêngôkre, even though they constitute a major theme in the elders' narratives. We set off from the toponimical enunciations in these stories to perceive the dynamics of place production and its relation to the historical splits between the subgroups, in which are also at stake today some state practices, such as land demarcation and the establishment of state limits, that, despite the contrast with mêbêngôkre territoriality, end up working as and idiom for the political relations between the subgroups.

Keywords: Territoriality. Places. Movement. 


\section{Introdução}

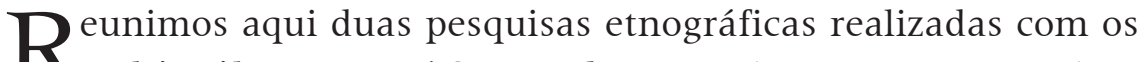
Mẽbêngôkre (Kayapó) ${ }^{1}$ e que devem muito a nossos respectivos diálogos com três anciões - Kupatô, Krwỳt (do subgrupo Kubẽkrãkêjn, TI Kayapó, Pará) e Iobal (do subgrupo Mẽtyktire, TI Capoto/Jarina, Mato Grosso). Buscaremos dialogar sobre narrativas - cujo principal mote são as andanças - que se encontram como uma mesma forma de conhecimento e se cruzam em determinados lugares evidenciando uma rede de relações estabelecida entre os subgrupos mẽbêngôkre, para além das separações históricas e políticas estabelecidas. Tomando como ponto de partida as narrativas toponímicas, buscamos reunir referências para a realização de uma etnografia da vivência da territorialidade em movimento. Observamos as tensões e desdobramentos que se estabelecem entre a territorialidade e organização sociopolítica mẽbêngôkre e o processo de regulamentação fundiária engendrado pelas práticas estatais - que historicamente têm tomado o movimento como negação da relação com a terra e consequentemente do direito a ela. Os deslocamentos mẽbêngôkre aparecem também como uma questão clássica e controversa na produção etnológica sobre este povo, como buscaremos desenvolver adiante.

Muitos relatos sobre andanças se iniciam com kubẽ kêt kam ou krõrõ kêt kam, traduzidas como "quando não tinha brancos" ${ }^{2 "}$ ou "quando ainda não havia a pacificação". Essas expressões são utilizadas para localizar as histórias em um tempo em que os não indígenas ainda não estavam presentes no cotidiano da aldeia. Além de delimitar um tempo, essas expressões também lidam com uma dinâmica de ocupação territorial diferente da atual. Elas se referem a uma época 
marcada pela grande mobilidade, quando se deslocavam por muitos dias sem vestígios dos brancos. Não à toa, entre as imagens utilizadas pelos Mẽbêngôkre para contrastar os períodos pré e pós "pacificação" (década de 1950), a mais proeminente delas é talvez aquela em que dizem que "só andavam no mato, feito queixadas". Segundo os mais velhos, a casa estava sempre vazia. Depois que chegaram os kubẽ, os Mẽbêngôkre passaram a ficar mais em casa, a esperá-los - e todos os bens materiais e simbólicos que traziam consigo.

Essa mobilidade, contudo, se dá de formas distintas e em certa medida persiste até hoje. Os mẽbêngôkre transitam bastante entre aldeias e cidades. Há também as caçadas coletivas realizadas pelos homens (mẽõtomõrõ) e que antecedem o fim de cerimônias de nominação. Mas já não praticam mais as expedições guerreiras e também as andanças sazonais que constituem o principal tema das narrativas dos anciãos, caracterizadas nesses relatos como $m \tilde{e}^{\prime} y^{3}$. Essas andanças ( $\left.m \tilde{e}^{\prime} y\right)$ eram realizadas especialmente no período da seca (mas não só), e podiam durar de algumas semanas até meses. Eram organizadas em geral em torno dos grupos masculinos que organizavam a política da aldeia. Segundo contou Krwỳt,

O chefe de um grupo falava para o seu pessoal: 'Como vamos fazer? Vocês dizem o nome de um lugar 4 que vocês gostem e pegamos os pequenos, os seus filhos, e vamos andar com eles para que comam mel e carne. Eles vão comer anta, queixada, jabuti e depois a gente volta e senta em casa'. Então, as pessoas respondiam: Sim, sim, sim. Vamos fazer nossa andança [mẽ 'y] para lá'. E falavam o nome de algum lugar. Então o chefe fazia o bẽn dizendo o nome do lugar e falava o que tínhamos que fazer. Quando amanhecia, todos saíam em andança. Andavam e acampavam.

Esse breve relato é seguido de uma descrição detalhada do cotidiano dos acampamentos, que não cabe colocar aqui. Uma descrição de certa forma similar (mas feita por um não-indígena) pode ser encontrada em Banner (1961). Em geral, construía-se um novo acampamento a cada dia, não muito distante do anterior, pois havia bastante coisas a serem carregadas, especialmente produtos da roça.

Werner ( 1983) chama esses deslocamentos de "trekking" em seu estudo e define-os como viagens terrestres que envolvem um grande número de pessoas durando algumas semanas, mas que preservam a 
intenção de retornar à uma aldeia principal. Turner (1992) compreende que as expedições (ou trekking) são apenas uma das formas de movimento e devem ser lidas dentro de uma compreensão mais ampla a respeito do movimento como um fato essencial da socialidade mẽbêngôkre. Essa definição de trekking parece ser demasiadamente restrita diante das múltiplas possibilidades de mobilidade Mẽbêngôkre, como as expedições guerreiras, as incursões cotidianas ao espaço fora da aldeia, as idas às cidades e às outras aldeias. Em outro extremo, é também usado o termo "perambulação"- que remete a um movimento indiscriminado, a ermo, aleatório. Diante disso, optamos aqui por nos referir ao movimento como tal, ou como andanças e deslocamentos, buscando nos afastar da sombra do excesso ou da ausência de intencionalidade premeditadas, ao mesmo tempo dando espaço à amplitude de interações (eventos) que se dão nessas emergência e conexão dos lugares.

Em meados do século XIX, os Mẽbêngôkre começaram a ocupar territórios cada vez mais a oeste, fugindo da crescente expansão não indígena (Verswijver, 1992) e construindo novas redes de caminhos e lugares. As cisões das aldeias - decorrentes, muitas vezes, de divergências quanto à forma de conduzir a aproximação com os não indígenas e que tinham como consequência uma hostilidade mútua entre os grupos recém-separados - fizeram com que os Mẽbêngôkre se espalhassem pela terra "feito um ramo" (krô pràk) e essas subdivisões são hoje consolidadas política e espacialmente. Se por um lado, a guerra era um grande combustível para as andanças, a "pacificação" consolidou certas subdivisões e as associou a determinados pedaços de terra. É comum ouvir os próprios Mẽbêngôkre se referirem a "Kayapó do Pará" e "Kayapó do Mato Grosso", que, na verdade, é uma apropriação que não coincide com o limite estadual, que é fixo. O que o Iobal considera "Mato Grosso" está em grande parte do Pará. Desse modo, a dinâmica sociopolítica dos Mẽbêngôkre também foi bastante afetada por todo histórico de contatos e pelo processo de reconhecimento de terras indígenas, atualmente fundamentais para a autonomia dos povos, mas que, consequentemente, impõe limites, gerando outras formas de ocupação territorial.

A partir das formas de movimento, observamos etnograficamente como se constitui a terra vivida pelos Mẽbêngôkre, com base em suas 
próprias práticas de conhecimento e em sua territorialidade específica. Uma face que essa tensão toma é o da diversidade de formas de ocupação territorial e estabelecimento de laços com a terra frente à conformação do entendimento de terra tradicionalmente ocupada que o processo de regularização fundiária impõe. Se a guerra, o trânsito intenso de grupos, os modos não-fixos de viver e os tantos elementos propulsores de movimentos são preeminentes nessa socialidade indígena, que efeitos tem o enquadramento de um povo em uma terra indígena, ou de subgrupos de um mesmo povo em diferentes terras indígenas? E o que escapa a terra indígena, na terra vivida?

\section{2 "Entre-Aldeias"}

No princípio da etnologia sul-americana, os povos Jê foram classificados como "tribos marginais" (Steward, 1946), sendo caracterizados como nômades, caçadores, coletores e detentores de práticas agrícolas insipientes. A caracterização dos povos Jê como nômades relegava-os a uma categoria de "sem terra". Em resposta a esse equívoco, os antropólogos começaram a utilizar o termo seminomadismo como modo de atenuar as ideias errôneas do movimento como perambulação à ermo e aleatória. No entanto, independentemente do termo utilizado, entendemos que essa dinâmica ainda é passível de descrição etnográfica, a fim de desvincular esses termos do ranço conceitual que carregam em si - como o atrelamento à subsistência e a concepção de "sem terra" - que mais obscurece do que põe luz à questão.

O obscurecimento da mobilidade como questão na etnologia sobre os Mẽbêngôkre nos parece fruto da ênfase nos estudos da estrutura social centrada na aldeia e da sua organização socioespacial - seja da abordagem de Turner (1992) enfatizando o espaço central/ masculino, seja da abordagem de Lea (2011) sobre as casas/feminino. Essa abordagem se põe em contraste com a dinâmica de habitação/ mobilidade que tem se apresentado em nossas pesquisas e em outras referências bibliográficas. Cabe mencionar que essa ênfase nos lugares "entre-aldeias" já foi abordada etnograficamente na análise da guerra mẽkrãgnoti (Versvijver, 1992) e da cosmopolítica mẽtyktire (Bolívar, 2014). Nesse sentido, pretendemos observar as relações que se dão ao 
longo dos caminhos e na nomeação de lugares, para além da aldeia. A partir de uma etnografia do movimento e das relações com os lugares nomeados, buscamos traçar as conexões dessa dinâmica com a descrição a respeito das aldeias, com o intuito de refletir posteriormente a respeito das implicações dessa perspectiva nos estudos da organização social mẽbêngôkre.

\section{A Mobilidade na Literatura}

As primeiras descrições e interpretações a respeito dos povos Jê habitantes da área de transição entre o cerrado do planalto central brasileiro e a floresta amazônica os caracterizavam como nômades, caçadores, coletores e detentores de práticas agrícolas incipientes. O movimento era suposto como resposta adaptativa de subsistência e o cerrado tido como um bioma marcado pela escassez.

Werner (1983) trata das andanças por um viés utilitarista e registra que os Mẽbêngôkre empreendem seus deslocamentos sazonais como forma de otimizar sua dieta de proteínas. Ele sai um pouco do idioma da escassez, dizendo que os Mẽbêngôkre já possuem uma dieta com quantidade considerável de proteínas enquanto estão na aldeia, mas que, durante a seca, quando a oferta de caça e pesca aumenta, eles promovem suas expedições com o objetivo de, dedicando mais tempo à busca por presas, conseguirem uma quantidade ainda maior de proteína animal. Esse incremento na dieta proporcionaria, segundo Werner (1983), maior resistência ao veneno da mandioca brava, que comporia a base da alimentação dos Mẽbêngôkre.

Turner (1992) discorda, pois, segundo ele, o modo como os Mẽbêngôkre empreendiam suas expedições, em grupos grandes e andando pouco a cada dia, não as tornava eficientes para a aquisição de mais caça do que se tinha normalmente nas aldeias. Para Turner (1992), o período na aldeia e o período no mato não representam distintos modos de sobrevivência, mas formas de organização social complementares. A matri-uxorilocalidade de segmentação - pois as unidades básicas de produção seriam as casas das famílias extensas daria lugar, durante as expedições, a um patrivirilocalidade coletiva, pois os homens, caçadores, funcionando como um grupo uno, dariam 
as coordenadas e guiariam o itinerário. Alternando entre vida na aldeia e nos acampamentos, a sociedade mẽbêngôkre contrabalancearia forças centrífugas - a tendência segmentar - e centrípetas - a solidariedade masculina nas andanças, reproduzindo a ordem e a estrutura social. Essa ideia de Turner tem o mérito de fugir das abordagens utilitaristas do neoevolucionismo cultural, mas ela não coloca o foco sobre o deslocamento. O período "no mato" é visto apenas como um contraponto a vida aldeã, gerando uma totalidade "estática".

Posteriormente, Posey (1992), numa abordagem mais ecológica, argumentou que os Mẽbêngôkre realizam um "sistema de agricultura nômade" e de manejo agroflorestal engenhoso, observando uma grande quantidade de práticas envolvendo o manejo de recursos do entorno das aldeias e áreas mais distantes, percorridas nos deslocamentos. Nesse sentido, não se trata de caçadores e coletores que vagam a ermo, mas de agricultores de corte e coivara que manejam diversos lugares percorrendo-os ciclicamente. Nos períodos de deslocamento, os Mẽbêngôkre carregam consigo produtos de suas roças; que não estão apenas nas aldeias. Os caminhos traçados envolvem capoeiras que são tidas como uma reserva de mudas e sementes, pomares e locais de caça; e, posteriormente, potenciais locais para reabertura de roças tendo em vista sua produtividade.

As dinâmicas sociopolíticas e territoriais descritas por Verswijver (1992) - os constantes deslocamentos, conflitos, cisões e recomposições dos subgrupos - se contrapõem a essa concepção da aldeia como unidade relativamente fechada e os grupos em movimento como coletividades mais coesas como descrito por Turner (1992). Há indícios etnográficos suficientes para conceber as aldeias e os subgrupos Mẽbêngôkre mais como arranjos relativamente transitórios do que como unidades estáveis. Segundo observou Leite (2007), as aldeias e acampamentos eram constantemente recompostos devido ao encontro de grupos que viajavam em tempos diferentes. Com efeito, os relatos dos anciões, como Kupatô, Krwỳt e Iobal, não podem ser tomados em si com a história de um subgrupo ou aldeia, mas “[...] antes como momentos dessas dispersões e encontros que são em conjunto a história de uma aldeia" (Leite, 2007, p. 12). 
Uma outra abordagem do movimento "entre-aldeias" e nas imediações das aldeias foi feita por Bolívar (2014), para quem nesses deslocamentos são revisitadas memórias e narrativas e vividas interações intensivas com outras agências que ali se colocam, como os karõ (imagens, espíritos) de antepassados, animais, plantas, etc. Esse conjunto de eventos que se dão ao longo do deslocamento constitui as pessoas mẽbêngôkre, trata-se “[...] portanto também [de] reorganizar os corpos, traçar marcas na pele, nos caminhos e na memória, estar ciente da importância do observado" (Bolívar, 2014, p. 173). Por meio da criação/nomeação de lugares, usados em diferentes escalas, e dos deslocamentos, os Mẽbêngôkre constituem desse modo a si e ao seu território.

\section{O Homem que Caminhava}

As trajetórias se dão por sequências de lugares nomeados em um itinerário gradual, conforme avança, ele se desdobra numa série de lugares e de caminhos, provocando uma imagem de que não há o espaço vazio. A própria passagem do tempo é marcada na terra pelos caminhos que se percorrem nela. Queremos mostrar agora um relato de Kupatô, que pode nos ajudar a pensar sobre o tema:

Eu sou Kupatô. Pykatôti foi onde eu nasci. Então eu fui pro mato, que era o Màtukrô. Eu era ibôktí. Depois eu voltei de novo pra minha aldeia bonita de Pykatô. Eu era ibôkti. Eu era assim. Era ibôkti. Depois eu saî pra'YYjỳre. Eu era assim, olha [gesto que cresceu mais um pouco]. Eu era mêbôkti. Então eu era ibôkti. Depois eu fui pra Pykarerekti. Aí eu voltei de novo pra minha aldeia bonita. Cheguei de novo em Pykatôti. Depois cheguei em 'Ydjỳre. Voltei pra 'Ydjỳre. Mas lá tinha gente ruim. Eles se xingavam (ari aben o punu o ba). Então eu estava com medo e corri junto com minha mãe. Então meu inhingêt Mrypati ele ficou assim [gemendo, gesto de que foi ferido]. Aí eu era ibôkti. Aí minha mãe me levou embora. A gente foi pra Amnikamrêk. No castanhal Amnikamrêk. Aí juntou com minha mãe e todo mundo fui embora, fui de novo pra 'Ydjỳre. Fomos pra 'Ydjỳre. Mas de novo estava ruim. Eles estavam brigando. Depois eu fui para o Bytire ${ }^{7}$. Eu corri de novo. Pra longe, pra outro kapôt $t^{8}$, pra outro kapôt, pra outro kapôt ruim. No Bytire, no Bytire. Eu era mêbôkti. Aí eu voltei de novo pra Pykatô. Voltei de novo. Eu era mẽbôkti, eu era mẽbôkti. Aí depois eu fui vindo, fui vindo, pra Pĩkàkadjôro. Longe Pĩkàkadjôro. Eu era mẽôkre, grande. 
Depois Pĩkàkadjôro. Longe! Aí eu fui pro mato dos Asuriní. Eu já era grande. Aí depois eu voltei de novo. Cheguei em Môkôktikre, cheguei em Môkôktikre. Eu ganhei meu mydjề, ganhei meu mydjê. Aí quando eu cheguei eu tirei meu mydjê. Aí de novo meu pênis ficou assim, sem nada ${ }^{10}$. Aí de novo eu fui embora, eu fui. Agora eu era mẽnoronyre. Eu já era mẽnoronyre. Depois de novo ganhei meu mydjê. Então eu peguei uma corda grande e fiz um cinto. Ai com essa corda também fiz meu ôkretã ${ }^{11}$. Eu já era grande. Eu mesmo tirei meu mydjê. Eu tirei meu mydjê. Meu cinto eu tirei. Então eu estava por aí e já virei mẽnoronyre. Depois eu voltei de novo pra Pykatôti. Eu era mẽnoronyre de verdade. Aí quando eu cheguei estava tendo cerimônia. Aí terminou a festa, terminou a dança. Eu era mẽnoronyre. Aí a gente foi de novo pro Bytire. Eu já era grande. De novo eu tinha mydjê. De novo eu tinha mydjê de verdade. Eu já era grande de verdade. Já tinha um mydjê e era forte de verdade. Depois eu cheguei de novo em Nhôjmydjare. A gente acampou em Nhôjmydjare. Depois voltei de novo pra Krãj'ãpare, acampou lá e chegou de novo. Eu nasci em Pykatô. Depois eu já era grande e voltei pra Tetyktire. Aí eu já era benjadjwỳry ${ }^{12}$ de verdade. Aí eu juntei todo mundo, dava comida. Aí eu fui pro castanhal, lá pra Noborina. O Tutu chama de Kikretum, mas lá é Noborina. Em Noborina eu fiquei só com kubẽ. Aí o kubẽ me falou "você vai ser benjadjwỳry". Então eu era benjadjwỳrỳ. Eu era benjadjwỳrỳ. Aí meu nome espalhou pro kapôt. Kupatô é benjadjwỳrỳ. Kupatô já é benjadjwỳrỳ.

Kupatô relatou isso quando foi perguntado se poderia contar a sua "história". Mas sua "história" e as passagens pelas suas fases de vida (mẽbôkti, mẽôkre, mẽnõrõnyre e benjadjwỳry) baseiam-se nas suas andanças e passagens por localidades nomeadas. Há uma espécie de entrelaçamento entre topônimos e categorias de idade, uma outra concepção da dualidade espaço/tempo. Kupatô nasceu e já foi pro mato. Foi até Màtukrô e quando voltou para sua aldeia, já era mẽbôkti. Depois foi para Ydjàre e cresceu mais um pouco. A ida a Pĩkàkadjôrô marca sua passagem para a categoria de mé'ôkre e a visita a Môkôktire sua transformação em mẽnõrõnyre. Ele volta para Tetyktire e já é benjadjwỳry. É como se as memórias de Kupatô fossem as memórias dos seus trajetos, e os lugares nomeados pelos quais passou representassem pontos na sua linha do tempo. Essa linha do tempo, portanto, não é uma reta, mas segue o trajeto de suas andanças. Podemos imaginar que falar sobre os lugares, e, principalmente, sobre as andanças entre eles, é uma forma de fazer emergir o passado (e o presente) diante de 
si. As narrativas do tipo são como mapas, ao mesmo tempo em que são storylines ${ }^{13}$.

Essas histórias, e também os nomes dos lugares, podem mudar de acordo com quem narra. É possível que determinada localidade mude de nome após um novo evento acontecer ali, ou mude de nome só para algumas pessoas. Os lugares-eventos vão se renovando e as pessoas vão constituindo suas histórias na mesma terra que seus antepassados. Diferentemente de outros povos - como os Yanesha (Santos-Granero, 1998) ou os Makuna (Cayon, 2010) - que têm bem marcado na paisagem os lugares dos acontecimentos míticos, os Mẽbêngôkre renovam esses lugares no transcorrer das gerações, pois novos eventos geram novos lugares. Há, por exemplo, um lugar chamado Djorodjo, em referência a um canto que foi trazido - os mẽbêngôkre "capturam os cantos", seja de animais, em sonho, seja de outros povos em situações de contato - e se cantou pela primeira vez ali. Antes, chamavam ali de "montanha do topo largo" (Krãjkagot). Outros nomes antigos, porém, são esquecidos. Como pessoas novas habitam aquela terra, ali há de se dar lugar também a novos lugares-eventos. O próprio castanhal Ydjỳre, citado por Kupatô, agora é chamado pelos mais novos de Pi'ykôny (castanhal novo). Há bastante tempo inexplorado, ele foi reencontrado pelos mais jovens quando retomaram uma velha prática de coletar castanha para vender para os kubẽ. O que era uma importante fonte de bens na época do SPI, quando Kupatô explorava Ydjỳre, retoma agora seu papel importante na economia mẽbêngôkre, com a exploração de Pi'ykôny e tantos outros castanhais.

A intensa dinâmica de deslocamentos, que leva Kupatô a dizer que os Mẽbêngôkre eram "feito porcos-selvagens", criou traços de memória sobre o corpo da terra, lugares-eventos nomeados, que se conectam em uma rede de caminhos, que se estende para além dos limites reconhecidos como terras indígenas e operam em uma dinâmica própria. Se inicialmente a caracterização dos Mẽbêngôkre como "nômades" ou "de índole perambulante" foi um meio de negá-los o acesso à terra, sem buscar uma compreensão mais aprofundada dessas práticas, da perspectiva apresentada pelos velhos mẽbêngôkre os deslocamentos produzem lugares-eventos e ao nomeá-los são integrados à sua terra, criando uma relação de pertencimento. 
Afastamo-nos, então, da concepção de um falso nomadismo que sugere que os grupos não fazem mais do que se deslocar de uma forma indiscriminada, havendo uma negação da relação, do vínculo, ou até mesmo do pertencimento, entre pessoas e lugares. A "terra dos mẽbêngôkre", diferentemente do que pressupõe a categoria de Terra Indígena, pode assumir novas formas, seja na forma como é percorrida nas expedições, seja nos discursos. E quando a "terra dos mẽbêngôkre" adquire novos contornos, os próprios Mẽbêngôkre assim o fazem. Mas o que os Mẽbêngôkre querem dizer quando falam em "nossa terra"?

\section{Pyka}

O surgimento de expressões indígenas traduzíveis como "nossa terra" tem sido observado em diferentes contextos etnográficos, implicando diversas concepções de T/terra e de socialidade. Coelho de Souza (2015) nota entre os Kisêdjê que o surgimento de expressão "nossa terra" não se referia a terra como matéria ou passível de propriedade, mas a uma rede de lugares nomeados, como um recurso intangível, uma fonte criativa à qual os próprios Kisêdjê estariam conectados por uma teia vital.

Entre os Mẽbêngôkre, o conceito de pyka (terra) vem sendo utilizado de diversas formas. Assim como seu "correspondente" na língua portuguesa, a palavra apresenta uma polissemia que buscaremos apresentar aqui. Utilizada tanto para o solo quanto, hoje em dia, para fazer referência à Terra Indígena, ela possui ainda um outro uso algo que se aproxima de "aldeia", como veremos - que pode nos dar uma pista sobre o que os Mẽbêngôkre querem dizer quando falam da "nossa terra".

Entre os usos cotidianos da palavra, pyka pode significar "chão", solo. Há pelo menos oito classificações de solo (Cooper et al., 2005), de acordo com cor e textura, como pykajaka (terra branca), pykatyk (terra preta), pykati (areia), etc. Nesse sentido, quando se quer dizer que algo está no chão, diz-se que está "na terra" (pyka bê). Dessa mesma forma, diz-se que os mortos estão "deitados na terra" (pyka kam nõ). Outro uso, esse mais recente, é para se referir à terra mẽbêngôkre fruto da demarcação. Os mẽbêngôkre se referem à área demarcada, à Terra 
Indígena, como "mẽ ba nhõ pyka" (nossa terra) ou, utilizando um "nós" inclusivo, "gwaj ba nhõ pyka". Há também uma outra forma de se utilizar pyka: quando se quer saber a aldeia de alguém, perguntase qual a sua pyka; quando, assistindo a algum vídeo, se quer saber em qual aldeia se passa a cerimônia em questão, pergunta-se qual é aquela pyka. Uma pessoa, quando quer dizer onde nasceu, diz que é sua pyka djwỳj ( $p y k a$ de verdade). Prestemos atenção em um trecho de uma narrativa de Kupatô:

Contei para você os nomes todos para você anotar no seu papel. Eu andei no mato de verdade. Andei ali, andei lá, andei lá. Eu falei para você o nome dos rios, nome dos matos. Eu andei e vi tudo isso. "Você viu isso tudo?" Vi! Eu andei, eu andei. Quem cresceu aqui não fala direito não sabe, não viu as coisas. Mas eu cresci há muito tempo, andei muito, vi muito. Vai chegar alguém e perguntar: "Onde está quem fez essa pyka? Quem foi?" Ele não sabe mesmo. Mas eu te contei tudo, você sabe. "Quem te contou isso? Kupatô me contou isso". Eu fiz essa pyka. Eu fiz Mojkarakô, eu fiz a pista de pouso. Depois eu voltei. Eu fiz. Quando eu era cacique eu levei todas as coisas para lá eu andei pelo mato. Vi tudo direitinho. No mato tem rio, tem castanhal, tem muito peixe. Vi tudo direitinho. Sei todos os nomes. Hoje as pessoas não conhecem os lugares, mas eu andei tudo. Eu sei o nome de todos os rios, todos os matos, todas as pyka. Eu vi todos os matos, eu fiz todas as pyka.

Um ponto que chama atenção é quando ele fala em "fazer pyka" (pyka nhipêj). Além de Kupatô relatar que andou por todas as pyka, ele também as fez. O primeiro impulso foi de traduzir o termo, nesses contextos, por "lugar". Pyka nhipêj seria então "fazer lugar". Teríamos, portanto, pyka como o solo, como terra indígena (em um uso mais contemporâneo) e como um termo genérico para lugares. Mas se, em todos esses casos, traduzirmos simplesmente por "terra" - explorando sua polissemia, nas línguas mẽbêngôkre e portuguesa -, poderíamos então estar mais atentos para a ideia de "equivocação" (Viveiros de Castro, 2004), ou a afirmação da intraduzibilidade (aqui potencialmente produtiva) de conceitos em jogo em determinadas relações interculturais, como no caso das disputas de terra com quais os povos indígenas lidam.

Outro ponto que devemos notar é que Kupatô diz que andou "pelos matos, rios e $p y k a^{\prime \prime}$, distinguindo, assim, três domínios diferentes. Nota- 
se também que, quando ele diz que fez $p y k a$, ele se refere às aldeias A'ukre e Môjkarakô. Logo, podemos dizer que pyka é um "lugar" de tipo distinto dos outros. O verbo que acompanha cada um desses domínios também é diferente: Kupatô viu todos os matos, enquanto "fez" todas as pyka, referindo-se às aldeias que criou. Guardemos essa ideia de "fazer" (nhipêj), que exploraremos adiante.

A partir disso, podemos afirmar que pyka é um termo utilizado, em determinadas ocasiões, para se referir à ideia de "aldeia". Ocorre, no entanto, que ao perguntar a um Mẽbêngôkre como se fala "aldeia" em sua língua, ou se alguém checar um dicionário mẽbêngôkre-português, descobrimos que a tradução usual para "aldeia" é krĩ, mesmo que essa palavra seja cotidianamente pouco utilizada com essa finalidade. Krĩ é literalmente "sentar", na sua forma plural ou indicando um sentido mais habitual. A ideia de aldeia estava ligada, assim, a um período de "assentamento" entre as andanças. Há ainda outras expressões utilizadas para as aldeias do passado, mẽmõrõdjà ou mébadjà (algo como "instrumento/local das andanças", numa tradução livre), que as relacionam explicitamente à mobilidade. De todo modo, em um material didático em língua mẽbêngôkre recentemente produzido pelos professores mẽbêngôkre, há uma sessão intitulada "Krĩ" e que mostra os nomes das aldeias mẽbêngôkre da atualidade.

Mas então qual seria a diferença entre krĩ e pyka, no sentido de aldeia? Está em jogo aqui, acreditamos, uma transformação nas expressões cotidianas da língua mẽbêngôkre relacionada a transformações decorrentes do contato no que se refere às próprias concepções de "aldeia" e o modo mẽbêngôkre de habitar a terra. As aldeias passaram, pelo menos semanticamente, de "assentamento", de um "instrumento" das andanças, para a uma ideia de "terra" passível de ser feita, como nos mostra Kupatô. O verbo "fazer" na língua mẽbêngôkre, nhipêj, está relacionado à produção material de algo. Kupatô, na narrativa apresentada acima, liga a feitura da aldeia ao seu trabalho braçal de abertura da pista de pouso. Assim, "fazer" aqui tem um pouco do sentido de "produção", um dispêndio de energia que gera um produto. "Fazer a terra" implica então um objeto material como resultado final, uma entidade palpável. Retomaremos isso em breve. 
Iobal, em outra narrativa, diz que para fazer uma aldeia olhavase a pyka, plantava-se a roça, construía-se as casas e, então, tinha-se a krĩ. Ao contar a história de determinado lugar, por exemplo, Iobal lembrou que uma senhora verificou se a terra era boa para plantar, cavando, pegando a terra e cheirando-a. Por isso, a partir deste evento, nomearam o lugar Pykabãrã, que significa "cheirar a terra", e ali se construiu uma aldeia. Pensemos em outra fala de Kupatô. Ele diz, em determinado momento, "Pykatôti kam krĩ raj". Kam é um sufixo que indica localidade, podendo ser a frase acima traduzida como "em Pykatôti há uma aldeia grande". Pykatôti aqui não é aldeia, mas o lugar nomeado onde ela se encontrava. A diferença é sutil, mas não irrelevante. A krĩ não é Pykatôti, mas está em Pykatôti.

A literatura, e os próprios Mẽbêngôkre mais jovens, dizem que Pykatôti é o nome da grande aldeia mẽbêngôkre do passado, onde todos se reuniam antes das cisões que geraram os subgrupos atuais. Digo os "Mẽbêngôkre mais jovens", pois se prestarmos atenção novamente na fala de Kupatô, Pykatôti não é o nome da aldeia, mas do lugar onde ela estava. A "coisa" nomeada não era a aldeia, mas o lugar. Hoje em dia, no entanto, a entidade nomeada é a própria aldeia. A'ukre, por exemplo, foi primeiramente construída em um lugar chamado A'ukre. Ela acabou mudando de local anos depois, mas o nome foi junto. O que queremos dizer aqui é que a aldeia é hoje uma entidade palpável e assim passível de uma nomeação que não ocorria no passado. Pensemos em diferentes "gerações" de aldeia. Pykatôti, do final do século XIX, é na verdade o nome do lugar onde foi erguida. As aldeias contemporâneas mais antigas da T.I. Kayapó são Kubẽkrãkêj, Kôkrajmôrô e Gorotire. Esses nomes na verdade são nomes dos subgrupos "pacificados" separadamente, referem-se a uma coletividade de pessoas, não a lugares. Já os nomes aldeias mais recentemente criadas são na maior parte dos casos uma questão de escolha. Há muitas aldeias cujos nomes remetem a lugares antigos, muitas vezes bastante distantes do sítio onde foram erguidas, numa espécie de "rememoração afetiva". É o caso de Djorodjo, Pykarãrãkre, Kôkôku'êdjà, Ngôjamrôti.

Podemos pensar, seguindo Wagner (1986), que os nomes funcionariam como um "corte" em um mar de indiferença, algo 
que distingue um certo elemento de outros que são de algum modo semelhantes a ele. Pensar dessa forma é encarar o nome como um "ponto de referência": o símbolo faz uma ligação "direta" com o simbolizado, discriminando-o de outros elementos do mesmo tipo. Se as aldeias não possuíam nomes, talvez não houvesse a necessidade de distinguir uma aldeia de outra. O que era distinguível eram os lugares, dos quais a nominação era questão de um esforço simbologizante mais acentuado. Nesse contexto, as aldeias eram "apenas" uma clareira e casas de palha, dispostas de maneira mais ou menos semelhante independentemente do lugar. É claro que a construção de uma aldeia "muda" o lugar, se considerarmos que o "lugar" é muito mais do que localização espacial. Mas é importante deixar claro que a relação entre aldeia e lugar não é meramente uma relação de conteúdo e continente. Dessa maneira, quando falo aqui que os nomeados eram os lugares ou as aldeias, não se trata de uma dissociação absoluta entre os dois. Ainda assim, linguisticamente, a distinção era entre "lugares", ainda que seus nomes tenham passado a incluir no seu significado a ideia de uma assentamento, isto é, ainda que tenham sido metaforizados. Essa distinção hoje é entre aldeias, e no período da "pacificação" era entre os diferentes subgrupos que se separaram, como ilustra o nome das aldeias contemporâneas mais antigas. A diferença nessas duas simbolizações - isto é, nos nomes de lugares ou de aldeias - parece indicar uma transformação na ideia que se tinha de aldeia, encadeada pela "pacificação".

Retomando a distinção entre krĩ e $p y k a$, quando se referem a ideia de aldeia, temos na verdade duas noções distintas: a primeira está ligada à aldeia como um "assentamento", uma lugar "entre-andanças"; a segunda a uma ideia de uma entidade passível de ser produzida, com um esforço físico, e transportável, como mostra o caso de A'ukre.

Não é objetivo aqui explicar a escolha da palavra pyka, "terra", para essa segunda noção. Mas é possível explorarmos a polissemia da palavra e prestarmos atenção no seu uso também para se referir à terra fruto dos procedimentos administrativos do Estado. Assim como as aldeias, a área de domínio dos Mẽbêngôkre não era uma entidade nomeada, mas (parte dela) passou a ser após os procedimentos estatais. 
Todas as seis T.I.s homologadas onde habitam os Mẽbêngôkre possuem nomes. De certa forma, podemos pensar que essas "terras" também foram produzidas, no sentido do esforço de cuidá-las, protegê-las e negociá-las com os kubẽ.

Quando os Mẽbêngôkre falam da "Mẽbêngôkre nhõ pyka" (a terra dos Mẽbêngôkre), estão pensando em pyka como aldeia? Poder-se-ia argumentar que pyka é simplesmente a tradução mais fácil do português "terra", utilizado, não tendo relação com o pyka como aldeia. Mas, se toda tradução é uma traição, podemos supor que os Mẽbêngôkre também carregam, ao traduzir, uma gama de outros significados que estão relacionados ao termo pyka.

\section{Entre "partes" e "todos"}

Para imaginar que significados são esses, é importante que nos detenhamos um pouco sobre um aspecto que está diretamente ligado a um sentimento de unidade que a terra indígena e o próprio etnônimo mẽbêngôkre pode gerar em determinados contextos. Existe uma ideia há algum tempo já rebatida, aquela que supõe que uma aldeia mẽbêngôkre (e jê de forma geral) funcione como uma unidade autossuficiente, um "todo" fixo. Na verdade, "[...] a aldeia é um 'todo' muito particular, nunca um 'todo' para todo mundo, o tempo todo" (Gordon, 2006, p. 193).

Gordon (2006) tinha em mente a discussão acerca da chefia mẽbêngôkre, argumentando que o benjadjwỳrỳ (cacique) não era o chefe de uma aldeia inteira, mas o chefe de sua "turma". O "todo" como aldeia (a visão de Turner) era na verdade composto de partes que constantemente se separavam e construíam outro "todo" em outro lugar, isto é, depois de conflitos, um grupo construía outra aldeia em outro local.

A aldeia é uma entidade mais ou menos transitória, que pode manter-se como uma unidade por um certo tempo, como pode também fracionar-se em novas unidades, estruturalmente idênticas à anterior. (Gordon, 2006, p. 193) . 
Mas cremos que ao mesmo tempo que ela pode fracionar-se em novas unidades, ela pode ser ela mesma uma "parte" de um "todo" maior. A esfera política é uma boa ilustração dessa variação fractal.

Quando começaram as cisões, como descrito por Verswijver (1992), os grupos que se separavam mantinham distância mútua. De modo que, se considerarmos a configuração das aldeias em 1992 (Verswijver, 1992), havia apenas dez comunidades, bastante afastadas entre si. Hoje, com uma proliferação de aldeias e também com um grande aumento populacional, há um número muito maior de comunidades e uma maior facilidade (relativa) de transporte entre elas. Além disso, elas se articulam em associações civis indígenas, seus membros estão em constante contato na cidade e por meio dos rádios. Em suma, o universo mẽbêngôkre de interações imediatas aumentou de maneira muito significativa. Em relação à chefia, isso fica claro com as novas configurações de aldeias, com a emergência de associações civis criadas e geridas pelos Mẽbêngôkre e com o concomitante desenvolvimento de novos espaços, posições e relações políticas. No plano do associativismo, organizações como a Floresta Protegida contam com um presidente que "despacha" em nome de um conjunto de aldeias. Demarchi (2014) comenta que a posição de Akjabôrô como líder dos Mẽbêngôkre do Pará, se deu após Raoni ser considerado líder dos Mẽbêngôkre do Mato Grosso. O "todo", nesse caso, seria todos os Mẽbêngôkre e suas várias aldeias. As "partes", os "do Pará" e os "do Mato Grosso".

No plano ritual e das "festas", esse jogo de "partes" e "todos" também aparece. Cohn (2005, p. 89) associa os mêtoro (as festas) ao verbo mẽbêngôkre amĩrin (aparecer). Seria uma ocasião em que as pessoas fariam aparecer seus nêkrêj, os adornos e prerrogativas rituais, mobilizados durante as cerimônias. Os nêkrêj são as "riquezas intangíveis" citadas por Lea (2012). Com "pessoas partíveis" ela transmite a ideia de que a pessoa mẽbêngôkre é composta na verdade de "partes", os nomes e os nêkrêj de uso ritual, que circulam seguindo a mesma lógica e que, segundo ela, são propriedades das matricasas mẽbêngôkre. Apesar de cada nome e cada adorno ritual poder pertencer a uma variedade de pessoas, esses elementos podem se combinar de diferentes formas em cada uma delas, possibilitando uma quantidade 
ilimitada de pessoas. Mas, mais importantes do que as "partes" em si, são as relações que elas invocam. Cada nêkrêj ou nome possuído atesta uma relação com o antigo possuidor que o transmitiu. Esse antigo dono, dessa mesma forma, está relacionado a um dono mais antigo, e assim por diante. No fim da linha, temos quem originalmente "capturou" o artefato de um kubẽ (os não mẽbêngôkre). O caso do vestido vermelho é eficiente para ilustrar tal fato, pois sua captura é relativamente recente (Verswijver, 1992, p. 146). Quem hoje possui o direito de usálo comporta relações que remetem em última instância àquele que matou o kubẽ e obteve o vestido. Esse encadeamento de relações, que poderia ser feito para todos os nomes e nêkrêj de uma pessoa, levou Lea a trabalhar com ideia da pessoa como "compósito de relações". Inspirada no trabalho de Strathern (1988), que questiona retratar os melanésios com o conceito ocidental de indivíduo, Lea (2012, p. 410) "[...] em vez de focalizar a circulação de nomes e nekrêtx como tais, enfoca as relações que conectam as pessoas no processo de transmissão". O valor do objeto não reside somente na sua materialidade, mas também no fato de ser um veículo de relações. Isso é evidenciado pelo fato de que não se transmite o artefato em si, mas o direito de usá-lo. Nesse sentido, os rituais, momentos em que as pessoas "aparecem" (amirin) fazendo uso dos seus nêkrêj seriam formas de "exibir relações". Desse modo, itens como o vestido vermelho ou o guarda-chuva (também um nêkrêj utilizado em cerimônias) são claramente "signos" das relações estabelecidas com os brancos, assim como o rori-rori (um "capacete" cerimonial de penas) é um signo das relações estabelecidas com os Karajá.

Dessa mesma forma, as festas "modernas" também exibem relações, mas em um nível distinto. Festas de 19 de Abril, jogos esportivos mẽbêngôkre e aniversários de aldeias são cada vez mais presentes (Demarchi, 2014). Segundo o autor, nessas ocasiões, a aldeia que realiza a festa costuma convidar outras aldeias para participarem e poderem atestar a beleza das festas promovidas por ela. Para a realização de tais festas, é necessário um grande montante de mercadorias e verbas que garantam uma boa estrutura. Se os rituais "exibem relações", essas novas festas exibem as relações que cada aldeia consegue mobilizar para 
realiza-las a contento e em escala adequada. É importante conseguir participar de projetos com os kubẽ como forma de obter mais recursos, habilitando-se, dentre outras coisas, a realizar eventos que chamem a atenção. Vereadores e prefeituras são comumente mobilizados para ajudar a financiar a festa. Nessas ocasiões, é como se quem aparecesse (amirin) não fosse as pessoas, e sim a aldeia, exibindo para outras aldeias os frutos (mercadorias) que suas boas relações com os kubẽ podem gerar, como apontou Demarchi (2014). Se mostrar os nêkrêj em uma cerimônia de nominação é uma forma de explicitar uma relação direta ou a relação de um antepassado com um kubẽ (geralmente por meio da guerra), mostrar às outras aldeias uma boa estrutura em uma festa de aniversário (Demarchi, 2014) é também uma forma de explicitar as relações estabelecidas com kubẽ (agora por meio da troca e negociação). Da mesma forma que as pessoas, as comunidades também são "compósitos de relações".

Certa vez, a comunidade A'ukre conseguiu comprar um grande gerador por meio da coleta de castanhas. Após efetuarem a troca das castanhas pelo motor, passaram de barco "desfilando" com ele pelas outras aldeias, ao som de fogos de artifício. Imagino que não haja uma forma mais explícita de amirĩn. É importante lembrar que o motor era algo que remetia à toda a comunidade e que os homens que o mostravam para as outras aldeias eram vistos como homens de A'ukre, não de algum grupo mais restrito. A intenção é mostrar às outras aldeias sua capacidade de se mobilizar e entrar em contato com agentes externos para a obtenção de novos recursos.

Hoje em dia, cercada por limites, a(s) terra(s) dos Mẽbêngôkre funciona $(\mathrm{m})$ também como uma unidade, principalmente na luta política pela terra. Do mesmo modo que os todos podem ser partes de outros todos, as pyka (aldeias) dos Mẽbêngôkre podem constituir uma pyka em um nível superior. Na luta pelas "suas terras", os Mẽbêngôkre têm como mote a defesa da "sua terra". No Pará, fala-se dos Mẽbêngôkre do Mato Grosso e vice-versa, mas, em Brasília, fala-se simplesmente dos Mẽbêngôkre. Da mesma forma, as terras mẽbêngôkre constituem aquilo que chamam de "mẽ ba nhõ pyka", ou a "nossa terra". Assim como a outra pyka, a aldeia, ela também congrega suas partes e também 
é palco para as relações que as constituem. Ela também é construída, protegida e foi "produzida" em um esforço tremendo de negociação com o Estado brasileiro.

\section{Limites e Outras Formas de Ocupação}

A partir da ênfase da territorialidade mẽbêngôkre no movimento, buscaremos aqui trazer algumas reflexões a respeito da tensão que se estabelece entre essa perspectiva e o processo de regulamentação fundiária engendrado pelas práticas estatais buscando observar as consequências da delimitação de diferentes, porém contínuas, das terras indígenas para subgrupos que se reconhecem como um mesmo povo.

Inicialmente Verswijver (Proc. n. 3.503/1982, fl.123) considera que a falta de comunicação e a inviabilidade dos parentes se visitarem - devido à ocupação não-indígena que se instalou entre as aldeias aumentou a tensão entre os subgrupos Mẽbêngôkre. Nesse sentido, apesar de cada subgrupo reivindicar a regularização de uma parcela do território histórico de deslocamentos, se estabelece a reivindicação conjunta que as terras indígenas sejam contínuas, Kromai declarou:

Irmão nosso, Kuben-krã-kein, Gorotire e Kokraimoro, tudo espalhado. Branco chegou aqui e separou nosso povo. Agora Kayapó tudo longe. Visitar irmão tem que passar escondido na mata, fugindo das fazendas. Não está certo. Terra Kayapó tem que ser uma só. Não pode ficar dividida. (Lea; Ferreira, 1984, p. 253)

Uma interessante observação sobre essas relações está registrada no filme Taking Aim (1993) - cuja filmagem se iniciou em 1985 - no qual os Mẽtyktire e os Mẽkrãgnoti dialogam por meio do envio de vídeo cartas entre si, transcrevo abaixo parte deste diálogo:

Noyremu Mẽtyktire:

Chefes Kayapós, hoje eu thes falo sobre nossas terras. Esta terra foi um dia um único país. Os brancos fizeram com que nos separássemos em diversos grupos cada um com seus próprios chefes. Temos que permanecer unidos e defender nossas terras, eu não gosto da nossa divisão em várias aldeias. Eu estou me dirigindo a todos os chefes Kayapós. Eu tenho uma visão de nossas terras como um único país. Isso é o que lhes descrevo. Será que somos ignorantes simplesmente porque vivemos na floresta? [...] Eu 
estou lhes enviando esta mensagem em vídeo para todos os chefes das nossas diversas aldeias. Minhas palavras foram diretas e honestas, eu gostaria de receber suas respostas.

Bepgogoti Mẽkrãgnõtire:

Metuktire, não venham em minhas terras nesta estação seca. Quando vocês receberem minha mensagem escutem minhas palavras cuidadosamente. Eu cresci nas margens deste rio, o Rio Iriri me pertence, Rio Roykore me pertence. Não venham a Gogogotoy. Tebakoytu bem como Ngua'krete me pertencem. Estes lugares pertencem a mim, Bepgogogty. Kapoto foi aonde eu cresci. Todos estes lugares fazem parte de meu país. Não venham a Kentinyuru.

As falas demonstram duas perspectivas, a primeira coloca em primeiro plano a unidade territorial mẽbêngôkre e a segunda reafirma as segmentações internas historicamente constituídas. Mencionamos a divisão dos Mẽbêngôkre em "Kayapó do Pará" e "Kayapó do Mato Grosso" - no qual apenas os Mẽtyktire compõem a segunda categoria - todavia, notamos a partir das falas de Iobal e Bepgogoti que essa divisão não corresponde aos limites estatais.

Primeiro eu vou falar que pra nós não tem essa divisão de estado, essa divisão de território. Quando nós vivíamos de cá pra lá o lugar por onde nós vamos passando e deixando um nome é nosso território que nós vivíamos. [...] antes do contato nós considerávamos todo esse território nosso, mas depois dessa divisão de estado, as demarcações de terra, nós assumimos ser os donos do nosso território. (Iobal)

Tomamos como exemplo a região do Kapôt, cerrado considerado o centro da ocupação Mẽkrãgnõtire (antes da cisão deste grupo) durante o século XX, a qual Iobal e Bepgogotise referem como onde cresceram. Com o reconhecimento das terras indígenas o Kapôt ficou dentro dos limites da TI Capoto/Jarina, habitada pelos Mẽtyktire, estabilizando uma diferença que até pelo menos 1964 era fluida, havendo o trânsito de segmentos desses subgrupos entre si. Em sua enunciação toponímica Iobal privilegia os nomes dos lugares no Mato Grosso por onde passou, pois considera que só tem a prerrogativa de falar dos nomes desses lugares - apesar de ter vivido parte da sua vida e ter seus pais enterrados no que hoje é o Pará. Dessa forma, observamos que a marcação das redes de lugares e deslocamentos em 
terras indígenas reforça divisões políticas internas, todavia cabe notar que essa subdivisão materializada nos limites administrativos se enraíza, em alguma medida, em outros "sistemas" de direitos territoriais. Cabendo, assim, observar as diferenciações e fluxos entre "dentro" e "fora", limites e interfaces são capazes de criar novas rupturas, bem como novas alianças.

Versvijwer (1992, p. 269) posteriormente observa, como um evento pós-contato, a aproximação entre os grupos Mẽbêngôkre. Até mesmo os grupos que mantinham maior antagonismo entre si até a década de 1970: como os Gorotire e os Xikrin; os Mẽkrãgnoti e os Kubẽkrãkêjn, e os Mẽkrãgnoti do Norte e Centrais. A realização de reuniões envolvendo os chefes Mẽbêngôkre (como o encontro de Altamira em 1989), o compartilhamento de dificuldades de lidar com as pressões externas, a comunicação via rádio e a possibilidade de visitas por meio de deslocamentos aéreos são elencados pelo autor como elementos decisivos para a constituição de um senso de unidade entre os grupos. Segundo o autor, a resistência Mẽbêngôkre diante das formas de pressão externas fez emergir um outro nível de autoconsciência social e política, um fortalecimento.

\section{Considerações Finais}

Buscamos apresentar neste artigo inquietações diversas que surgiram no âmbito de nossas pesquisas de mestrado, a proposta é dialogar com reflexões de dois caminhos em curso, cientes que essas trajetórias etnográficas e conceituais aqui apresentadas ainda são passíveis de inúmeros desdobramentos.

Por meio da concepção da produção e da nomeação de lugareseventos, pretendemos nos distanciar da representação do espaço homogêneo, da perspectiva do nomadismo estanque que não produz relações. Nesse movimento, nos deparamos com narrativas toponímicas que evidenciam relações de participação íntima que se estabelecem entre as pessoas e a terra, provendo uma relação de pertencimento recíproco. Nesse sentido, empreendemos a análise das subdivisões sociopolíticas Mẽbêngôkre, notando que as narrativas toponímicas dos diferentes anciões referem-se a uma região contínua e conectada, todavia seus 
itinerários diferem, uma vez que refletem suas trajetórias pessoais. A delimitação da terra indígena cria o dentro e o fora colocando limites que devem ser vividos e, nesse sentido, se tornam lugares, assim, em algumas circunstâncias, esses limites são acionados como fronteiras em outros, como na memória e na narrativa, eles inexistem.

O que queremos dizer sobre a pyka dos Mẽbêngôkre? Nossa intuição é que a terra indígena e os "limites" que ela impõe gerem em determinados contextos uma entidade análoga à aldeia, um "todo" em nível distinto e que se relaciona com outros todos do mesmo tipo. Sejam os Mẽbêngôkre do Pará frente aos Mẽbêngôkre do Mato Grosso, seja os Mẽbêngôkre como um todo frente aos kubẽ. Se o que os Mẽbêngôkre chamam de "nossa terra" pode ser uma entidade análoga à aldeia, é porque ela também é feita, produzida. E isso só pode ser feito caminhando sobre a terra, traçando caminhos e nomeando lugares e num processo de constante luta frente aos kubẽ. De modo que sua habitação não pode ser de outro tipo que não permanente, mesmo que a ideia de permanência, no sentido mẽbêngôkre, possa ser atualizada pela narrativa toponímica e a reprodução dos trajetos pela enumeração dos lugares-eventos e das histórias que se passaram ali.

Nesse sentido, é necessário ser interpelado pela experiência da terra no encontro etnográfico, mover-se nessa rede de lugares nomeados, para entender os elementos que permeiam essas relações, esses lugares que envolvem corpos de pessoas e o corpo da terra provendo uma relação de pertencimento com a terra vivida pelos Mẽbêngôkre, por meio da mobilidade na qual a terra se confunde como o processo, ao mesmo tempo que o constitui.

\section{Notas}

1 Os Kayapó se auto denominam Mẽbêngôkre, que pode ser traduzido como "o povo do buraco d'agua" (Turner, 1992), sendo um povo falante de língua da família Jê, do tronco linguístico Macro-Jê.

2 Nessa expressão, a palavra que os mẽbêngôkre traduzem por "branco" é kubẽ, cujo sentido mais exato é "não-mẽbêngôkre". Hoje em dia, no entanto, ela é comumente traduzida por "branco".

3 É possível que algumas formas de deslocamento praticadas hoje - como as idas a cidades para fazer compras - guardem algum tipo de relação com o mẽ $y$ praticado em outros tempos. Os anciãos costumam dizer que uma das finalidades de se passar um tempo andando no mato era "comer carne", enquanto os mais novos hoje 
gostam de falar que "caçam" também no supermercado. No entanto, os anciãos com frequência dizem, em um tom de certa forma nostálgico, que os Mẽbêngôkre não praticam mais o mée'y.

4 A palavra em língua mẽbêngôkre utilizada aqui é $p y k a$, cujos possíveis significados serão discutidos no decorrer do texto.

5 Espécie de discurso formal realizado pelos chefes, com o objetivo de iniciar ou terminar formalmente alguma atividade. A tonalidade muda e até mesmo algumas palavras adquirem novas formas durante o bẽn.

6 Categoria de idade, meninos entre 5 e 8 anos.

7 Como os Mẽbêngôkre, especialmente os mais velhos, se referem ao Rio Xingu.

8 Campo, cerrado, clareira na mata ou qualquer área aberta.

9 Estojo peniano.

${ }^{10}$ Em expedições guerreiras, até os meninos mais novos recebem um estojo peniano, pois um homem não deve aparecer na frente dos seus inimigos sem ele (Turner, 1966). No entanto, no caso dos meninos mais jovens, ele é apenas provisório, apenas para o momento da expedição. Por isso, Kupatô o retirou e ficou sem nada.

11 Colar de penas utilizado pelos rapazes que passaram pela cerimônia mé̃itykre, descrita por Turner (1966).

12 Traduzido pelos mẽbêngôkre como "cacique".

13 Algo como o caso dos Warlpiri apresentado por Glowczweski, que "[...] formam conexões, mapas e agenciamentos através dos sonhos, [...] uma rede de histórias totêmicas incorporadas na paisagem, transformando, assim, uma multiplicidade de linhas Jukurrpa em um Jukurrpa metamórfico, o sonhar como espaço-tempo [...]" (Glowczweski, 2014, p. 25), onde jukurrpa é o vernáculo warlpiri para o que em inglês se conhece como Dreaming, uma importante prática dos povos aborígenes australianos.

\section{Referências}

BANNER, Horace. O índio Kayapó em seu acampamento. Boletim do Museu Paraense Emílio Goeldi, [Paraná], n. 13. 1961.

BASSO, Keith. Wisdom sits in places. Landscape and language among the Western Apache. Albuquerque: University of New México Pres, 1996.

BOLÍVAR, Edgar. Influências Mẽbêngôkre: cosmopolítica em tempos de Belo Monte. 2014. 365 p. Tese (Doutorado em Antropologia Social) Universidade Federal Fluminense, Niterói, 2014.

CAYÓN, Luis. Penso, logo crio: a teoria makuna do mundo. 2010. 465 p. Tese (Doutorado em Antropologia Social) - Universidade de Brasília, Brasília, 2010.

COOPER, M.; TERAMOTO, E. R.; VIDAL-TORRADO, P.; SPAVOREK, G. Learning soil classification with the Kayapó Indians. Scientific Agriculture, [S.l.], v. 62, n. 6, p. 604-06, 2005.

DELEUZE, Guilles; GUATARRI, Felix. O Anti-Édipo: capitalismo e esquizofrenia 1. 2. ed. [S.l.]: Editora 34, 2011. 
GALLOIS, Dominique Tilkin. Não sabíamos que existiam limites: Catálogo Índios, nós. Lisboa: Museu de Etnologia, 2000.

GALLOIS, Dominique Tilkin. Terras ocupadas? Territórios? Terras Indígenas? In: RICARDO, Fanny (org.). Terras indígenas e unidades de conservação da natureza. São Paulo: ISA, 2004. p. 37-41.

GALLOIS, Dominique Tilkin. Apropriação e gestão de uma terra: a experiência Waiãpi (Amapá, Brasil). Interethnic@-Revista de Estudos em Relações Interétnicas, [S.l.], v. 3, n. 1, p. 27-40, 2013.

LEA, Vanessa. Riquezas Intangíveis de Pessoas Partíveis: os Mẽbêngôkre (Kayapó) do Brasil Central. São Paulo: Edusp e Fapesp, 2012. LEA, Vanessa. Área indígena Kapoto: laudo antropológico. Campinas: UNICAMP, Instituto de Filosofia e Ciências Humanas, 1997.

LEA, Vanessa; FERREIRA, Mariana. A guerra no Xingu: Cronologia. In: RICARDO, Carlos A. (ed.). Povos Indígenas no Brasil. [S.l.]: [s.n.], 1984. p. 246-258.

LEITE, M. E. Introdução. In: POVOS MEBÊNGÔKRE, PANARÁ E TAPAJUNA. Atlas dos Territórios Mebêngôkre, Panará e Tapajuna. [S.l.]: Funai; MEC; Sipam; Associação Ipren-re e Petrobrás Cultural, 2007.

GLOWCZEWSKI, Barbara. Devires Totêmicos: Cosmopolítica Do Sonho. Edição Bilíngue: Português-Inglês. São Paulo: [s.n.], 2015.

HIRSCH, Eric. Introduction. Landscape: between Place and Space. In: HIRSCH, E.; O'HANLON, M. (org.). Anthropology of Landscape: Perspectives on Space and Place. Oxford: Clarendon Press. 1995. p. 1-30.

POSEY, Darrell. Interpreting and applying the "reality" of indigenous concepts: what is necessary to learn from the natives. In: REDFORD, Kent Hubbard; PADOCH, Christine. Conservation of neotropical forests: working from traditional resource use. Columbia University Press, 1992.

SANTOS-GRANERO, Fernando. Writing history into the landscape: space, myth, and ritual in contemporary Amazonia. American Ethnologist, [S.l.], v. 25, n. 2, p. 128-148, 1998.

STEWARD, Julian H. Handbook of South American Indians. [S.l.]: [s.n.], 1946. v. 2.

STRATHERN, Marilyn. Contemporary moments: Land as intellectual property. In: CHESTERS, T. (ed.), Land Rights: Oxford Amnesty Lectures. Oxford: Oxford University Press, 2009. p. 13-38. 
TURNER, Terence. Os Mebengokre Kayapó: história e mudança social, de comunidades autônomas para a coexistência interétnica. In: CARNEIRO DA CUNHA, Manuela (org.). História dos índios no Brasil. São Paulo: FAPESP; SMC;Companhia das Letras,1992. p. 311-38.

VERSWIJVER, Gustaaf. Proc. 008211094-8 3503 FUNAI. Comunica que a DGPI incluirá em suas previsões de trabalho de 1983, estudos sobre a área indígena Kapoto através de composição de GT. 1982.

VERSWIJVER, Gustaaf. The club-fighters of the amazon: warfare among the Kaiapo Indians of Central Brazil. Rijksuniversiteit te Gent, 1992.

VIVEIROS DE CASTRO, Eduardo. Perspectival anthropology and the method of controlled equivocation. Tipití: Journal of the Society for the Anthropology of Lowland, South America, v. 2, n. 1, p. 1, 2004. WAGNER, Roy. Symbols that stand for themselves. University of Chicago Press, 1986.

WERNER, Dennis. Why do the Mekranoti trek? In: HAMES, Raymond B.; VICKERS, William T. (ed.). Adaptive responses of native amazonians. Nova Iorque: Academic Press, 1983. p. 225-38.

Recebido em 03/11/2017

Aceito em 30/04/2018

\section{Ester Oliveira}

Doutoranda do Curso de Antropologia Social da Universidade de Brasília E-mail: ester.otire@gmail.com

\section{João Lucas Moraes Passos}

Doutorando do Curso de Antropologia Social da Universidade de Brasília E-mail: joao.moraespassos@gmail.com 